\title{
Peran Escrow Services sebagai Variabel Pemoderasi di Marketplace ${ }^{\star}$
}

\author{
Ratna Dewi Kusumawati ${ }^{a, *}$, Didi Achjari ${ }^{b}$ \\ a Program Studi Akuntansi Universitas Bina Insani \\ ${ }^{b}$ Fakultas Ekonomika dan Bisnis Universitas Gadjah Mada
}

\begin{abstract}
Previous studies show that Perceived Effectiveness of Escrow Service (PEES) affects the relationship. In e-commerce, trust can be seen as a trust in the community of sellers and trust in intermediaries. The purpose of this study is to investigate the role of PEES to moderate relationship between trust in intermediaries and repurchase intentions, and between trust in the community of sellers and repurchase intention. This research was administered to 138 respondents through online survey. The findings indicate that PEES moderates not only the relationship of trust in intermediaries and repurchase intentions, but also the relationship between trust in the community of sellers and repurchase intentions.
\end{abstract}

Keywords: trust to community of seller; trust to intermediary; perceived effectiveness of escrow services; repurchase intentions; e-commerce

\begin{abstract}
Abstrak
Penelitian terdahulu menunjukkan bahwa Perceived Effectiveness of Escrow Service (PEES) mempengaruhi hubungan kepercayaan kepada komunitas penjual dan intensi pembelian kembali. Dalam konteks e-commerce, kepercayaan dapat dipandang sebagai kepercayaan kepada komunitas penjual dan kepercayaan kepada perantara. Tujuan dilakukannya penelitian ini adalah untuk meneliti peran moderasi PEES terhadap hubungan antara kepercayaan kepada perantara dan intensi pembelian kembali, serta kepercayaan kepada komunitas penjual dan intensi pembelian kembali. Penelitian ini dilakukan kepada 138 responden melalui survei daring. Temuan dari hasil uji menunjukkan bahwa PEES memoderasi hubungan antara kepercayaan kepada perantara dan intensi pembelian kembali, serta kepercayaan kepada komunitas penjual dan intensi pembelian kembali.
\end{abstract}

Kata kunci: kepercayaan kepada komunitas penjual; kepercayaan kepada perantara; perceived effectiveness of escrow services; intensi pembelian kembali; e-commerce

JEL Classification: M49

\footnotetext{
${ }^{\star}$ Paper ini merupakan bagian dari tesis penulis

${ }^{*}$ Penulis Korespondensi: Universitas Bina Insani, Jl. Siliwangi No. 6, Rawa Panjang, Kota Bekasi, Indonesia, Telp.: +62-21-82436886. E-mail: ratnadewi1991@gmail.com.
} 


\section{Pendahuluan}

Indonesia memiliki penetrasi penggunaan internet yang cukup tinggi. APJII (2018) mempublikasikan bahwa penetrasi penggunaan internet tahun $2017 \mathrm{di}$ Indonesia mencapai 54,7\% dari keseluruhan populasi atau sekitar 143,26 juta jiwa. Meningkatnya penetrasi pengguna internet di Indonesia ternyata merupakan salah satu faktor yang mendorong pertumbuhan e-commerce yang sangat pesat di Indonesia (Okefinance, 2017), konsisten dengan temuan penelitian Ho et al. (2007) bahwa penetrasi pengguna internet berpengaruh terhadap pertumbuhan e-commerce dalam suatu negara. CNN Indonesia memberitakan bahwa menurut Asian Nikkei Review, konsumen e-commerce tahun 2017 secara total telah mencapai 35 juta, atau naik sebesar 11 juta sepanjang tahun 2017 (cnnindonesia.com, 2018), dengan nilai transaksi e-commerce pada tahun 2017 yang mencapai 85 triliun rupiah (mediaindonesia.com, 2018). Karena pertumbuhan yang pesat tahun 2017, banyak investor berlomba untuk melakukan investasi pada sektor e-commerce, yang selama tahun 2017 angka investasinya mencapai lebih dari USD5 miliar (swa.co.id, 2018).

Jenis mekanisme $e$-commerce, yang mendukung aktivitas dari e-commerce untuk terus bertumbuh, cukup beragam dalam praktiknya. Menurut Turban et al. (2010), salah satu mekanisme e-commerce adalah electronic marketplaces atau pasar elektronik. Pada mekanisme pasar daring, ASEAN UP (2018) mempublikasikan beberapa pasar besar yang di antaranya adalah Tokopedia sebagai pemimpin pasar tahun 2017 (Liputan6.com, 2017), Elevenia, Bukalapak, dan Shopee.

Aktivitas konsumen dalam kesuksesan e-commerce sangat dipengaruhi oleh adanya trust atau kepercayaan (Corbitt et al., 2003; Vos et al., 2014). Kepercayaan diperlukan dalam e-commerce karena adanya ketidakpastian (uncertainty) (Grabner-Kraeuter, 2002). Hal tersebut karena konsumen tidak bisa melihat barang yang dijual, adanya kemungkinan tindak penipuan (Lee \& Turban, 2001), dan adanya tingkat risiko persepsian yang terasosiasi dengan pembelian daring (Anderson \& Srinivasan, 2003). Terkait dengan ketidakpastian, tindak penipuan yang dilakukan dari aktivitas jual beli daring melalui jejaring sosial nyatanya memang pernah dialami oleh beberapa masyarakat (Sindonews.com, 2017). Pada lingkungan dengan ketidakpastian, menurut Grabner-Kraeuter (2002), ternyata munculnya kepercayaan dapat mengurangi risiko persepsian dari transaksi yang dilakukan dan juga kompleksitas informasi dalam e-commerce.

Beberapa penelitian menyatakan bahwa kepercayaan konsumen dalam $e$ commerce tidak hanya mengurangi risiko persepsian, namun juga dapat memengaruhi repurchase intention dalam e-commerce. Penelitian tersebut diantaranya dilakukan oleh Qureshi et al. (2009) dan juga Anantoro \& Achjari (2017). Anantoro \& Achjari (2017) dalam penelitiannya mengungkapkan dan memberikan bukti empiris bahwa kepercayaan kepada komunitas penjual dan kepercayaan kepada perantara berpengaruh terhadap intensi pembelian kembali.

Saat ini sistem pembayaran dalam marketplace seperti Tokopedia dan Elevenia difasilitasi oleh jasa sistem escrow (Marketeers, 2016; Tokopedia, 2018). Escrow 
service atau jasa escrow di Indonesia lebih dikenal dengan sebutan rekening bersama atau RekBer (Srisadono, 2018; Tiara et al., 2016). Escrow menurut Pavlou \& Gefen (2004) adalah mekanisme pemberian garansi dari sisi finansial atas transaksi yang dilakukan dengan cara memastikan bahwa kesepakatan penjual dan pembeli sudah terpenuhi terlebih dahulu, barulah kemudian uang yang ada dalam escrow akan diberikan kepada penjual.

Beberapa penelitian telah dilakukan terkait jasa escrow ini, di antaranya adalah penelitian Pavlou \& Gefen (2004), Hu et al. (2004), Antony et al. (2006), Fang et al. (2014), dan masih banyak lagi penelitian dengan topik jasa escrow. Penelitian yang dilakukan oleh Fang et al. (2014) menguji peran moderasi Perceived Effectiveness of E-commerce Institutional Mechanisms (PEEIM) yang di dalamnya meliputi jasa escrow dan kartu kredit, pada hubungan kepuasan, kepercayaan, dan juga intensi pembelian kembali. Hasil penelitian menunjukkan bahwa PEEIM secara negatif memoderasi hubungan antara kepercayaan dan intensi pembelian kembali (Fang et al., 2014).

Penelitian yang dilakukan oleh Fang et al. (2014) hanya menguji kepercayaan kepada penjual dan kepuasan terhadap intensi pembelian kembali saja. Padahal, menurut Hong \& Cho (2011) dan Chong et al. (2003) kepercayaan dalam e-commerce dapat dipandang dalam dua kategori, yaitu kepercayaan terhadap penjual dan juga kepercayaan terhadap intermediary atau pihak perantara.

Adanya bukti empiris pengaruh kepercayaan kepada perantara yang juga dapat memengaruhi intensi pembelian kembali menjadi peluang untuk mengembangkan penelitian yang dilakukan oleh Fang et al. (2014). Kemudian beberapa marketplace di Indonesia sendiri menurut Marketeers (2016) sudah menyediakan jasa escrow, sebagai bagian dari PEEIM (Fang et al., 2014). Berdasarkan latar belakang tersebut, pertanyaan yang ingin dijawab dalam penelitian ini adalah apakah perceived effectiveness of escrow service dapat memoderasi hubungan kepercayaan kepada perantara dengan intensi pembelian kembali?

Penelitian ini hanya akan menggunakan perceived effectiveness of escrow service sebagai salah satu dimensi dalam PEEIM untuk menjawab pertanyaan penelitian. Hal tersebut dikarenakan tingkat pengguna kartu kredit untuk berbelanja secara daring masih rendah (Detikfinance, 2017), dan oleh karenanya, akan sulit untuk mendapatkan responden. Detikfinance (2017) menyebutkan bahwa hanya sekitar $2 \%$ masyarakat yang membayar transaksi daring mereka di e-commerce dengan kartu kredit. Survei yang dilakukan oleh DailySocial (2015) kepada 763 responden juga menyatakan bahwa pengguna kartu kredit untuk bertransaksi secara daring masih rendah. DailySocial (2015) menyatakan bahwa hanya 7\% dari total responden yang memilih pembayaran menggunakan kartu kredit. 


\section{Landasan Teori dan Hipotesis}

\subsection{Kepercayaan}

Kepercayaan menurut Mayer et al. (1995) adalah kesediaan atas harapan satu pihak terhadap pihak lain bahwa tindakan yang penting bagi pihak yang mempercayai akan dilakukan pihak lain sesuai ekspektasi. Kepercayaan merupakan sebuah ekspektasi bahwa pihak yang dipercaya oleh pihak yang mempercayai tidak akan mengambil keuntungan atau bertindak secara oportunistik (Gefen et al., 2003). Pada kondisi yang diliputi oleh ketidakpastian dan juga risiko, seperti kondisi pada internet shopping di mana konsumen tidak dapat melihat barang yang akan dibeli, kepercayaan merupakan faktor yang penting (Lee \& Turban, 2001). Selain itu, kepercayaan dianggap sangat penting karena kepercayaan membantu para konsumen untuk mengatasi berbagai persepsi mengenai adanya ketidakpastian dan juga adanya risiko dengan para penjual dalam e-commerce (McKnight et al., 2002).

\subsection{Kepercayaan Kepada Perantara dan Komunitas Penjual}

Ada dua aspek dalam kepercayaan konsumen di e-commerce, keduanya adalah kepercayaan kepada para penjual dan kepercayaan kepada perantara (Chong et al., 2003; Hong \& Cho, 2011). Verhagen et al. (2006) menekankan bahwa ketika para peneliti akan mempelajari perilaku pembelian dari konsumen dalam pasar elektronik, peneliti harus mempertimbangkan tiga pihak, yaitu pembeli, penjual dan juga perantara. Shapiro (1987) menjabarkan kepercayaan kepada perantara (disebutkan sebagai guardian of trust) sebagai sebuah perasaan aman yang dirasakan terkait dengan adanya upaya dari perantara untuk memberikan pengamanan yang efektif terhadap pihak yang mempercayai. Sedangkan Verhagen et al. (2006) dalam penelitiannya mendefinisikan kepercayaan kepada perantara sebagai kepercayaan pada perantara bahwa perantara memastikan kejujuran, dependability dan juga reliabilitas penjual dalam pasar elektronik.

Penelitian yang dilakukan oleh Pavlou \& Gefen (2004) memaparkan bahwa kepercayaan terhadap penjual di sebuah e-commerce merupakan hubungan oneto-many di mana konsumen memiliki kepercayaan terhadap komunitas penjual dan tidak hanya kepada satu penjual. Kepercayaan kepada komunitas penjual merupakan kepercayaan subjektif dari para konsumen bahwa ketika mereka melakukan transaksi dengan para penjual di sebuah marketplace, transaksi tersebut akan sama atau sesuai dengan ekspektasi mereka (Pavlou \& Gefen, 2004).

Adanya ketidakpastian yang kemudian dipandang menjadi risiko oleh para konsumen dalam lingkungan e-commerce dapat diatasi dengan kepercayaan (Mayer et al., 1995). Mayer et al. (1995) memaparkan bahwa kepercayaan ini diperlukan dalam situasi yang berisiko. Pavlou \& Gefen (2004) dalam artikelnya juga menyatakan bahwa kepercayaan merupakan mekanisme untuk mengurangi adanya ketidakpastian ketika dihadapkan dengan ketidakpastian sosial, yaitu pembeli tidak bisa mengetahui apa yang akan dilakukan oleh pihak lain dalam 
transaksi. Menurut Gefen (2000), kepercayaan dapat membuat orang-orang menciptakan pengorganisasian yang komprehensif dalam berinteraksi dengan orang lain, meski sebenarnya kepercayaan tidak dapat membuat pembeli mengontrol atau mencegah adanya tindakan yang tidak diinginkan. Ketika konsumen sudah dapat mengatasi ketidakpastian dengan kepercayaan mereka, kemudian konsumen memutuskan untuk melakukan transaksi.

Selain memengaruhi niat untuk bertransaksi, beberapa studi menyatakan bahwa kepercayaan dalam e-commerce juga dapat memengaruhi niatan untuk melakukan pembelian kembali dalam e-commerce. Penelitian tersebut diantaranya dilakukan oleh Qureshi et al. (2009) dan Anantoro \& Achjari (2017). Anantoro \& Achjari (2017) dalam penelitiannya mengungkapkan dan memberikan bukti empiris bahwa kepercayaan kepada komunitas penjual dan kepercayaan kepada perantara berpengaruh terhadap intensi pembelian kembali. Ganesan (1994) memaparkan bahwa kepercayaan yang dimiliki oleh konsumen dapat menurunkan biaya transaksi dalam exchange relationship, mengurangi risiko-risiko yang muncul dari tindakan oportunistik para penjual dalam hubungan jangka panjang sehingga kepercayaan tersebut akan meningkatkan orientasi jangka panjang terhadap penjual.

Berdasarkan paparan sebelumnya, dapat dikatakan bahwa baik kepercayaan kepada perantara maupun kepercayaan kepada komunitas penjual ini muncul untuk mengatasi ketidakpastian yang ada dalam lingkungan e-commerce. Konsumen yang bertransaksi dalam e-commerce akan menemui lingkungan dengan ketidakpastian dan juga kompleksitas. Maka dengan adanya kepercayaan, baik kepercayaan kepada perantara maupun kepercayaan kepada komunitas penjual:

H1: Kepercayaan Kepada Komunitas penjual berpengaruh positif terhadap Intensi Pembelian Kembali

H2: Kepercayaan Kepada Perantara berpengaruh positif terhadap Intensi Pembelian Kembali

\subsection{Perceived Effectiveness of Escrow Services}

Menurut Patton \& Jøsang (2004), escrow services atau jasa escrow, merupakan salah satu bentuk pembayaran perantara yang digunakan oleh e-commerce. Jasa escrow merupakan salah satu tipe jasa 'risk-relief' dalam e-commerce, karena penyedia jasa escrow ini akan mengamankan transaksi yang dilakukan oleh pembeli maupun juga penjual, dengan menampung pembayaran hingga transaksi selesai (Hu et al., 2004).

Pavlou \& Gefen (2004) menyatakan bahwa sistem escrow akan menjamin transaksi yang akan dilakukan dari sisi finansial dengan memastikan bahwa pengiriman pembayaran kepada penjual dilakukan saat kedua pihak (penjual dan pembeli) setuju sudah terpenuhinya kesepakatan yang telah dibuat. Merujuk Chong et al. (2003), dalam transaksi daring ada ketidakpastian yang melekat. Jasa escrow yang ada dalam e-commerce, secara teori dapat menyelesaikan isu keti- 
dakpastian yang ada, namun bergantung salah satunya pada penilaian pembeli mengenai seberapa efektif jasa escrow yang ada (Pavlou \& Gefen, 2004). Oleh sebab itu, perceived effectiveness of escrow service oleh Pavlou \& Gefen $(2004,2005)$ didefinisikan sebagai sejauh mana para pembeli mempercayai bahwa layanan escrow yang ada bisa menjamin jika transaksi pembeli dengan penjual di marketplace akan terpenuhi sesuai dengan harapan pembeli.

Kepercayaan dalam beberapa penelitian terkait e-commerce merupakan variabel yang dapat memengaruhi intensi pembelian kembali (Qureshi et al., 2009), dimana kepercayaan dapat mengurangi adanya ketidakpastian dalam e-commerce. Hal ini dipandang penting karena ketidakpastian yang ada dapat menimbulkan beberapa risiko dalam transaksi di e-commerce (Grabner-Kräuter \& Kaluscha, 2003). Namun, kepercayaan bukanlah satu-satunya metode untuk mengurangi kompleksitas yang ada dalam e-commerce (Gefen, 2000). Kepercayaan hanya diperlukan dalam situasi yang berisiko (Mayer et al., 1995). Maka, ketika sebuah tindakan dapat dilakukan dengan kepastian dan tanpa risiko, kepercayaan tidak lagi diperlukan (Grabner-Kräuter \& Kaluscha, 2003).

Risiko aktual dan juga risiko persepsian dalam e-commerce dapat dikurangi oleh jasa escrow yang efektif dengan cara menyerap ketidakpastian yang terkait dengan pembayaran, kualitas produk, dan juga pengantaran (Pavlou \& Gefen, 2004). Selain itu, keefektifan dari jasa escrow sebagai salah satu mekanisme institusional akan membuat konsumen atau pembeli kurang bergantung pada kepercayaan untuk pembentukan intensi pembelian kembali (Fang et al., 2014). Fang et al. (2014) menambahkan bahwa ketika pembeli kurang percaya dengan mekanisme institusional yang efektif, maka pembeli memerlukan kepercayaan agar mereka terstimulasi untuk melakukan pembelian.

Berdasarkan paparan yang telah dijabarkan, maka dapat dikatakan bahwa pada lingkungan transaksi yang tidak pasti, yang menimbulkan berbagai risiko, diperlukan kepercayaan untuk memengaruhi pembeli memiliki intensi pembelian kembali. Namun, pada lingkungan dengan jasa escrow, di mana jasa escrow dapat mengurangi atau meminimalkan risiko, peran kepercayaan untuk memengaruhi intensi pembelian kembali akan berkurang. Dikarenakan kepercayaan hanya diperlukan dalam lingkungan atau kondisi yang berisiko:

H3: Perceived effectiveness of escrow services memoderasi hubungan Kepercayaan Kepada Komunitas Penjual terhadap Intensi Pembelian Kembali

H4: Perceived effectiveness of escrow services memoderasi hubungan Kepercayaan Kepada Perantara terhadap Intensi Pembelian Kembali

\section{METODE PENELITIAN}

Penelitian ini merupakan penelitian kuantitatif. Populasi dalam penelitian ini adalah masyarakat yang pernah melakukan pembelian di marketplace. Sampel dalam penelitian ini adalah masyarakat secara umum yang pernah berbelanja di marketplace yang memiliki sistem jasa escrow di Indonesia seperti Tokope- 
dia, Shopee, Elevenia, dan marketplace lainnya dalam kurun waktu enam bulan terakhir. Metode pengambilan sampel dalam penelitian ini didasakan pada purposive sampling. Peneliti melakukan pengumpulan data melalui fasilitas kuesioner daring yang didistribusikan kepada pada responden yang memenuhi kriteria sampel.

Kuesioner dalam penelitian ini mengadopsi instrumen dari penelitian-penelitian sebelumnya dan menggunakan skala Likert. Variabel Intensi Pembelian Kembali diukur dengan instrumen yang telah digunakan oleh Fang et al. (2014). Variabel Kepercayaan Kepada Komunitas Penjual dalam penelitian ini diukur dengan instrumen yang digunakan oleh Hong \& Cho (2011). Variabel Kepercayaan Kepada Perantara diukur dengan instrumen yang dikembangkan oleh Hong \& Cho (2011). Variabel Perceived Effectiveness of Escrow Services diukur dengan instrumen yang dikembangkan oleh Pavlou \& Gefen (2004). Peneliti melakukan pretest untuk memastikan bahwa pertanyaan dalam kuesioner sudah tepat, mudah dipahami, tidak ada salah penulisan, dan tidak adanya kesalahan pengukuran (Sekaran \& Bougie, 2013).

\subsection{Analisis Data}

Pengujian hipotesis dalam penelitian ini menggunakan Moderated Regression Analysis (MRA) melalui perangkat lunak SPSS. Sebelum dilakukan pengujian MRA, peneliti melakukan beberapa pengujian lain untuk menganalisis data yang telah didapatkan. Pengujian pertama yang dilakukan yaitu uji non-response bias. Responden yang merespons dengan terlambat dapat diasumsikan juga sebagai non-responden (Armstrong \& Overton, 1977), maka diperlukan pengujian non-response bias untuk mengetahui apakah respons terlambat bisa digabungkan dengan respons tepat waktu (Hartono, 2016), salah satunya dengan independen sample t test (Ghozali, 2018). Pengujian selanjutnya adalah uji validitas dan reliabilitas, uji asumsi normalitas, uji heteroskedastisitas, dan uji multikolinearitas. Pengujian hipotesis dilakukan dalam dua model yang ditunjukkan dalam Persamaan (1) dan (2). Persamaan (1) digunakan untuk menguji hipotesis 1 dan 3, dan Persamaan (2) digunakan untuk menguji hipotesis 2 dan 4.

$$
\text { Repurchase }=\alpha+\beta_{1} \text { TrustSeller }+\beta_{2} \text { PEES }+\beta_{3} \text { PEES_TrustSeller }+e
$$

Repurchase $=\alpha+\beta_{1}$ TrustIntermediary $+\beta_{2}$ PEES $+\beta_{3}$ PEES_TrustIntermediary $+e$

\section{Hasil Penelitian dan Pembahasan}

Sebelum mengumpulkan data, peneliti melakukan pretest kuesioner. Pretest kuesioner didistribusikan kepada 11 responden. Para responden memberikan umpan balik yang berisi masukan untuk perbaikan kuesioner penelitian ini. Setelah dilakukan pretest, peneliti mulai mendistribusikan kuesioner secara daring. 
Pengumpulan data dilakukan dengan bantuan Google Form. Proses pengumpulan data dilakukan selama dua minggu. Data yang didapatkan dan dapat diolah sejumlah 138. Berdasarkan keseluruhan data yang diperoleh, responden penelitian ini melakukan pembelian di pasar daring Shopee sebanyak $45 \%$, Tokopedia sebanyak 32\%, Bukalapak 16\%, dan pasar daring lain 7\%.

Data yang telah terkumpul diolah dengan melakukan beberapa pengujian sebelum diuji dengan menggunakan Moderated Regression Analysis untuk menguji hipotesis. Hasil pengujian non-response bias yang dilakukan menunjukkan bahwa tidak ada perbedaan antara respons awal waktu dan respons terlambat. Hasil pengujian validitas dan reliabilitas menunjukkan bahwa seluruh indikator dalam kuesioner ini valid dan reliabel. Hasil pengujian asumsi normalitas, multikolinearitas, dan heteroskedastisitas dapat dilihat pada Tabel 4.1.

Table 4.1: Hasil Uji Asumsi Normalitas, Multikolinearitas, dan Heteroskedastisitas

\begin{tabular}{lllll}
\hline \multirow{2}{*}{ Model } & \multirow{2}{*}{ Variabel } & Kolmogorov-Smirnov & \multirow{2}{*}{ VIF } & Uji Glejser \\
\cline { 5 - 5 } \cline { 5 - 5 } Model 1 & Kepercayaan Kepada Komunitas Penjual & 0,200 & & signifikansi \\
& PEES & & 20,496 & 0,318 \\
& PEES_TrustSeller & & 23,957 & 0,414 \\
Model 2 & Kepercayaan Kepada Perantara & 0,038 & 62,515 & 0,451 \\
& PEES & & 9,396 & 0,537 \\
& PEES_TrustIntermediary & & 14,934 & 0,725 \\
& & & 35,084 & 0,678 \\
\hline
\end{tabular}

Merujuk pada Tabel 4.1, hasil pengujian asumsi normalitas menunjukkan bahwa Model 1 terdistribusi secara normal dengan signifikansi 0,200, dan Model 2 tidak terdistribusi secara norma dengan signifikansi 0,038. Meskipun tidak terdistribusi secara normal, Central Limit Theorem mengungkapkan bahwa untuk ukuran $n$ yang besar, estimasi dari slope dan intercept akan mendekati distribusi normal dan data yang digunakan tetap valid (Rice, 2007). Hair Jr. et al. (2014) juga mengungkapkan ketika ukuran sampel lebih besar, peneliti dapat mengurangi fokus pada distribusi yang tidak normal. Hasil uji multikolinearitas dengan VIF menunjukkan bahwa terjadi multikolinearitas pada Model 1 dan 2 kecuali variabel Kepercayaan Kepada Perantara. Meski terjadi multikolinearitas, menurut Hartono (2018), ketika melakukan pengujian dengan MRA di mana ada variabel interaksi, sebenarnya tidak terjadi multikolinearitas meski nilai VIF-nya tinggi. Hasil uji heteroskedastisitas dengan Uji Glejser menunjukkan bahwa tidak terjadi heteroskedastisitas, di mana nilai p-value seluruhnya di atas 0,05.

Pengujian hipotesis dilakukan dengan menggunakan MRA pada kedua model. Hasil pengujian MRA dapat dilihat dalam Tabel 4.2. Tabel tersebut menunjukkan bahwa Hipotesis 1, 2, 3, dan 4 terdukung. Pada pengujian Model 1, hasil uji menunjukkan bahwa variabel Kepercayaan Kepada Komunitas Penjual, PEES, dan variabel interaksi Model 1 berpengaruh terhadap variabel dependen dengan signifikansi kurang dari 0,05. Hasil uji menunjukkan nilai $R$ Square sebesar 0,448 dan F sebesar 36,225. Variabel PEES pada Model 1 berpengaruh secara langsung terhadap variabel Intensi Pembeliaan Kembali, maka peran moderasi variabel 
Table 4.2: Hasil Uji Moderated Regression Analysis

\begin{tabular}{|c|c|c|c|c|c|c|}
\hline \multirow{2}{*}{ Model } & \multirow{2}{*}{ Variabel } & \multicolumn{2}{|c|}{ Unstandardized Coef } & Standardized Coef & \multirow{2}{*}{$t$} & \multirow{2}{*}{ Sig. } \\
\hline & & $\mathrm{B}$ & Std Error & Beta & & \\
\hline \multirow[t]{3}{*}{ Model 1} & TrustSeller & 1,162 & 0,352 & 0,960 & 3,302 & $0,001^{* *}$ \\
\hline & PEES & 1,343 & 0,313 & 1,350 & 4,296 & $0,000^{* *}$ \\
\hline & PEES TS & $-0,227$ & 0,084 & $-1,367$ & $-2,693$ & $0,008^{* *}$ \\
\hline \multicolumn{7}{|c|}{$\mathrm{R}=0,669 \mathrm{R}$ Square $=0,448$ Adj $\mathrm{R}$ Square $=0,435 \mathrm{~F}=36,225 \mathrm{Sig}=0,000$} \\
\hline \multirow[t]{3}{*}{ Model 2} & Trust Intermediary & 0,708 & 0,234 & 0,596 & 3,025 & $0,003^{* *}$ \\
\hline & PEES & 0,804 & 0,247 & 0,808 & 3,255 & $0,001^{* *}$ \\
\hline & PEES TI & $-0,097$ & 0,058 & $-0,636$ & $-1,672$ & $0,097^{*}$ \\
\hline
\end{tabular}

$\mathrm{R}=0,669$ R Square $=0,447$ Adj R Square $=0,435 \mathrm{~F}=36,098$ Sig $=.000$

Keterangan: ** Signifikan pada tingkat kepercayaan $5 \%$

* Signifikan pada tingkat kepercayaan $10 \%$

PEES pada Model 1 dapat dikelompokkan menjadi moderasi kuasi (Sekaran \& Bougie, 2013). Pengujian Model 2 menunjukkan bahwa variabel Kepercayaan Kepada Perantara dan PEES berpengaruh terhadap variabel dependen dengan signifikansi kurang dari 0,05. Variabel interaksi Model 2 berpengaruh terhadap variabel dependen pada tingkat kepercayaan 10\%, maka dapat dikatakan bahwa hipotesis 4 terdukung. Hasil uji menunjukkan nilai $R$ Square sebesar 0,447 dan F sebesar 36,098. Variabel PEES pada Model 2 berpengaruh secara langsung terhadap variabel Intensi Pembeliaan Kembali, maka peran moderasi variabel PEES pada Model 2 dapat dikelompokkan menjadi moderasi kuasi (Sekaran \& Bougie, 2013).

\subsection{Diskusi}

Hasil pengujian statistik mendukung hipotesis 1 dan 2 dari penelitian ini. Data menunjukkan bahwa kepercayaan terhadap komunitas penjual dan perantara memengaruhi intensi pembelian kembali secara positif. Konsisten dengan temuan Ganesan (1994), kepercayaan pembeli dapat mengurangi risiko yang muncul dari tindakan oportunistik dalam jangka panjang.

Selain itu, Hipotesis 3 pada penelitian ini - bahwa perceived effectiveness of escrow services memoderasi hubungan kepercayaan kepada komunitas penjual terhadap intensi pembelian kembali - juga terdukung secara statistik. Karena memiliki nilai beta yang negatif, maka dapat disimpulkan bahwa variabel Perceived Effectiveness of Escrow Services memoderasi hubungan Kepercayaan Kepada Komunitas Penjual dan Intensi Pembelian Kembali secara negatif. Hasil uji statistik menunjukkan bahwa ketika pembeli merasa bahwa jasa escrow efektif meminimalkan risiko yang timbul dari komunitas penjual, maka peran dari kepercayaan terhadap komunitas penjual untuk memengaruhi intensi pembelian kembali akan berkurang. Hal ini sejalan dengan Fang et al. (2014) yang menyatakan bahwa keefektifan dari jasa escrow akan membuat pembeli kurang bergantung pada kepercayaan untuk pembentukan intensi pembelian kembali.

Hipotesis 4 pada penelitian ini juga terdukung secara statistik, meskipun 
dengan tingkat kepercayaan 10\%. Hipotesis ini menyatakan bahwa Perceived Effectiveness of Escrow Services memoderasi hubungan Kepercayaan Kepada Perantara terhadap Intensi Pembelian Kembali. Nilai beta dari pengujian pada variabel interaksi bernilai negatif, mengindikasikan bahwa variabel PEES memiliki hubungan yang negatif dengan hubungan Kepercayaan Terhadap Perantara dan Intensi Pembelian Kembali.

Terdukungnya hipotesis 4 menunjukkan bahwa PEES tidak hanya memoderasi hubungan antara Kepercayaan Kepada Komunitas Penjual dan Intensi Pembelian Kembali, namun PEES juga terbukti dapat memoderasi hubungan Kepercayaan Kepada Perantara dan Intensi Pembelian Kembali. Hal tersebut memberikan bukti empiris bahwa dengan adanya escrow service yang dirasa efektif, konsumen akan mengurangi kecenderungannya untuk bergantung pada kepercayaan kepada perantara untuk pembentukan intensi pembelian kembali. Escrow service yang dirasakan efektif dapat memberikan perasaan aman terhadap lingkungan transaksi daring (Pavlou \& Gefen, 2004). Escrow service yang efektif juga menjamin bahwa transaksi akan terjadi sesuai dengan harapan pembeli (Pavlou \& Gefen, 2004) sehingga pembeli yakin bahwa perantara memastikan kejujuran, dependability, dan juga reliabilitas penjual dalam pasar elektronik.

Temuan lain dalam penelitian ini adalah variabel PEES juga memiliki dampak langsung terhadap variabel Intensi Pembelian Kembali. Hal tersebut dapat diartikan bahwa PEES memiliki peran langsung untuk memengaruhi intensi pembelian kembali. Adanya jasa escrow yang dianggap efektif oleh pembeli justru secara bersama-sama dengan kepercayaan kepada perantara dan kepada komunitas penjual memengaruhi intensi pembelian kembali.

\section{Kesimpulan, Keterbatasan dan Implikasi}

Penelitian ini dilakukan dengan tujuan menguji peran moderasi PEES terhadap hubungan kepercayaan, baik kepercayaan kepada perantara dan kepercayaan kepada komunitas penjual, terhadap intensi pembelian kembali. Penelitian ini dilakukan untuk mengembangkan penelitian Fang et al. (2014). Hasil dari pengujian yang dilakukan dalam penelitian ini menunjukkan bahwa perceived effectiveness of escrow service (PEES) terbukti memoderasi hubungan antara kepercayaan kepada perantara dan intensi pembelian kembali. PEES secara statistik juga terbukti memoderasi hubungan kepercayaan kepada komunitas penjual dan intensi pembelian kembali. PEES sendiri juga memiliki pengaruh langsung terhadap intensi pembelian kembali. Oleh sebab itu, peran moderasi PEES dalam penelitian ini disebut sebagai moderasi kuasi. Selain pengaruh moderasi dari PEES, penelitian ini juga menunjukkan adanya pengaruh kepercayaan kepada komunitas penjual dan kepercayaan kepada perantara terhadap intensi pembelian kembali.

Beberapa keterbatasan yang menjadi kendala dalam penelitian ini antara lain penelitian ini tidak mengukur harga produk yang dibeli oleh para responden. Menurut Kim \& Benbasat (2009), harga sangat berhubungan dengan persepsi pembeli mengenai ketidakpastian dan juga konsekuensi yang merugikan dari 
pembelian produk atau jasa. Kim \& Benbasat (2009) memaparkan bahwa risiko persepsian akan makin tinggi ketika barang yang dibeli makin mahal. Hal ini tentunya juga akan memengaruhi kepercayaan pembeli. Tingkat kepercayaan pembeli pada saat membeli barang mahal dengan barang yang murah mungkin berbeda. Keterbatasan lainnya dalam penelitian ini adalah bahwa penelitian ini menggunakan kuesioner dengan metode recall memori, di mana metode tersebut menurut Fang et al. (2014) rentan dengan memory recall bias. Untuk meminimalisir memory recall bias, bisa digunakan metode eksperimen maupun metode yang lainnya (Fang et al., 2014).

Berdasarkan hasil penelitian dan juga keterbatasan dalam penelitian ini, ada beberapa rekomendasi untuk melakukan penelitian selanjutnya, di antaranya adalah peneliti selanjutnya dapat mempertimbangkan dan mengeksplorasi lebih jauh pengaruh variabel harga ke dalam model penelitian serupa untuk mengetahui pengaruh dari variabel tersebut. Penelitian selanjutnya dapat mempertimbangkan untuk menggunakan metode eksperimen atau metode lain untuk mengurangi memory recall bias yang berpotensi muncul.

\section{Daftar Pustaka}

[1] Anantoro, A., \& Achjari, D. (2017). Pengaruh Kepercayaan kepada komunitas penjual, kepercayaan kepada situs dan risiko persepsian terhadap niat pembelian kembali di situs consumer-to-consumer e-commerce. Jurnal Ekonomi E Bisnis, 11(3), 163-177.

[2] Anderson, R. E., \& Srinivasan, S. S. (2003). E-satisfaction and e-loyalty: A contingency framework. Psychology \& Marketing, 20(2), 123-138. doi: https://doi.org/10.1002/mar.10063.

[3] Antony, S., Lin, Z., \& Xu, B. (2006). Determinants of escrow service adoption in consumer-to-consumer online auction market: an experimental study. Decision Support Systems, 42(3), 1889-1900. doi: https://doi.org/10.1016/j.dss.2006.04.012.

[4] APJII. (2018). Hasil survei penetrasi dan perilaku pengguna internet Indonesia 2017. Asosiasi Penyelenggara Jasa Internet Indonesia. Diakses pada 8 November 2018. https://apjii.or.id/content/read/39/342/ Hasil-Survei-Penetrasi-dan-Perilaku-Pengguna-Internet-Indonesia-2017.

[5] Armstrong, J. S., \& Overton, T. S. (1977). Estimating nonresponse bias in mail surveys. Journal of Marketing Research, 14(3), 396-402. doi: https://doi.org/10.1177/002224377701400320.

[6] ASEAN UP. (2018). Top 10 e-commerce sites in Indonesia 2018. Diakses pada 4 Oktober 2018. https://aseanup.com/top-e-commerce-sites-indonesia/.

[7] Chong, B., Yang, Z., \& Wong, M. (2003, September). Asymmetrical impact of trustworthiness attributes on trust, perceived value and purchase intention: a conceptual framework for cross-cultural study on consumer perception of online auction. In ICEC '03: Proceedings of the 5th international conference on Electronic commerce (pp. 213-219). doi: https://doi.org/10.1145/948005.948033.

[8] CNNIndonesia.com. (2018, 21 Februari). Sektor e-commerce tumbuh, tokopedia merajai pasar Indonesia. Diakses pada 6 November 2018. 
https:/ / www.cnnindonesia.com/teknologi/20180221105010-185-277674/ sektor-e-commerce-tumbuh-tokopedia-merajai-pasar-indonesia.

[9] Corbitt, B. J., Thanasankit, T., \& Yi, H. (2003). Trust and e-commerce: a study of consumer perceptions. Electronic Commerce Research and Applications, 2(3), 203-215. doi: https://doi.org/10.1016/S1567-4223(03)00024-3.

[10] DailySocial.id. (2015, 26 Juni). Survei: Di tahun 2015, metode pembayaran transfer bank masih terpopuler untuk belanja online. Diakses pada 2 November 2018. https: //dailysocial.id/post/transfer-bank-2015.

[11] Detikfinance. (2017, 6 Desember). Masyarakat RI masih nyaman belanja pakai uang Tunai. Diakses pada 24 Oktober 2018. https://finance.detik.com/moneter/d-3757175/ masyarakat-ri-masih-nyaman-belanja-pakai-uang-tunai.

[12] Fang, Y., Qureshi, I., Sun, H., McCole, P., Ramsey, E., \& Lim, K. H. (2014). Trust, satisfaction, and online repurchase intention: The moderating role of perceived effectiveness of e-commerce institutional mechanisms. MIS Quarterly, 38(2), 407-428, A1-A9.

[13] Ganesan, S. (1994). Determinants of long-term orientation in buyer-seller relationships. Journal of Marketing, 58(2), 1-19. doi: https://doi.org/10.1177/002224299405800201.

[14] Gefen, D. (2000). E-commerce: the role of familiarity and trust. Omega, 28(6), 725-737. doi: https://doi.org/10.1016/S0305-0483(00)00021-9.

[15] Gefen, D., Karahanna, E., \& Straub, D. W. (2003). Trust and TAM in online shopping: An integrated model. MIS Quarterly, 27(1), 51-90.

[16] Ghozali, I. (2018). Aplikasi analisis multivariate dengan program IBM SPSS 25 (Edisi 9, Cet. 9). Semarang: Badan Penerbit-UNDIP.

[17] Grabner-Kraeuter, S. (2002). The role of consumers' trust in online-shopping. Journal of Business Ethics, 39(1-2), 43-50. doi: https://doi.org/10.1023/A:1016323815802.

[18] Grabner-Kräuter, S., \& Kaluscha, E. A. (2003). Empirical research in on-line trust: a review and critical assessment. International Journal of Human-Computer Studies, 58(6), 783-812. doi: https://doi.org/10.1016/S1071-5819(03)00043-0.

[19] Hair Jr., J. F., Black, W. C., Babin, B. J., \& Anderson, R. E. (2014). Multivariate data analysis (7th edition). England: Pearson Education Limited.

[20] Hartono, J. (2016). Pedoman survei kuesioner: Mengembangkan kuesioner, mengatasi bias dan meningkatkan respon (edisi ke-2). Yogyakarta: BPFE.

[21] Hartono, J. (2018). Metodologi penelitian bisnis: Salah kaprah dan pengalaman-pengalaman (Edisi 6). Yogyakarta: BPFE.

[22] Ho, S. C., Kauffman, R. J., \& Liang, T. P. (2007). A growth theory perspective on B2C e-commerce growth in Europe: An exploratory study. Electronic Commerce Research and Applications, 6(3), 237-259. doi: https://doi.org/10.1016/j.elerap.2006.06.003.

[23] Hong, I. B., \& Cho, H. (2011). The impact of consumer trust on attitudinal loyalty and purchase intentions in B2C e-marketplaces: Intermediary trust vs. seller trust. International Journal of Information Management, 31(5), 469-479. doi: https://doi.org/10.1016/j.ijinfomgt.2011.02.001.

[24] Hu, X., Lin, Z., Whinston, A. B., \& Zhang, H. (2004). Hope or hype: On the viability of escrow services as trusted third parties in online auction environments. Information Systems Research, 15(3), 236-249. doi: https://doi.org/10.1287/isre.1040.0027.

[25] Kim, D., \& Benbasat, I. (2009). Trust-assuring arguments in B2C e-commerce: Impact of content, source, and price on trust. Journal of Management Information Systems, 26(3), 175-206. doi: https://doi.org/10.2753/MIS0742-1222260306. 
[26] Lee, M. K., \& Turban, E. (2001). A trust model for consumer internet shopping. International Journal of Electronic Commerce, 6(1), 75-91. doi: https://doi.org/10.1080/10864415.2001.11044227.

[27] Liputan6.com. (2017, 23 Agustus). Ini 10 toko online terbaik di Indonesia. Diakses pada 6 Oktober 2018. https://www.liputan6.com/tekno/read/3068210/ ini-10-toko-online-terbaik-di-indonesia.

[28] Marketeers. (2016, 29 Maret). Elevenia terapkan escrow system untuk jamin keamanan transaksi. Diakses pada 7 Oktober 2018. http://marketeers.com/ elevenia-terapkan-escrow-system-untuk-jamin-keamanan-transaksi/.

[29] Mayer, R. C., Davis, J. H., \& Schoorman, F. D. (1995). An integrative model of organizational trust. Academy of Management Review, 20(3), 709-734. doi: https://doi.org/10.5465/amr.1995.9508080335.

[30] McKnight, D. H., Choudhury, V., \& Kacmar, C. (2002). Developing and validating trust measures for e-commerce: An integrative typology. Information Systems Research, 13(3), 334-359. doi: https://doi.org/10.1287/isre.13.3.334.81.

[31] mediaindonesia.com. (2018, 6 Januari). Optimisme e-commerce di 2018. Diakses pada 8 November $2018 \mathrm{http}: / /$ mediaindonesia.com/read/detail/ 139499-optimisme-e-commerce-di-2018.

[32] Okefinance. (2017, 30 Agustus). Industri E-Commerce Semakin Berkembang, Indonesia Paling Pesat! Diakses pada 5 Oktober 2018. https:/ /economy.okezone.com/read/2017/08/30/320/1766098/ industri-e-commerce-semakin-berkembang-indonesia-paling-pesat.

[33] Patton, M. A., \& Jøsang, A. (2004). Technologies for trust in electronic commerce. Electronic Commerce Research, 4(1-2), 9-21. doi: https://doi.org/10.1023/B:ELEC.0000009279.89570.27.

[34] Pavlou, P. A., \& Gefen, D. (2004). Building effective online marketplaces with institution-based trust. Information Systems Research, 15(1), 37-59. doi: https://doi.org/10.1287/isre.1040.0015.

[35] Pavlou, P. A., \& Gefen, D. (2005). Psychological contract violation in online marketplaces: Antecedents, consequences, and moderating role. Information Systems Research, 16(4), 372-399. doi: https://doi.org/10.1287/isre.1050.0065.

[36] Qureshi, I., Fang, Y., Ramsey, E., McCole, P., Ibbotson, P., \& Compeau, D. (2009). Understanding online customer repurchasing intention and the mediating role of trust-an empirical investigation in two developed countries. European Journal of Information Systems, 18(3), 205-222. doi: https://doi.org/10.1057/ejis.2009.15.

[37] Rice, J. A. (2007). Mathematical statistics and data analysis (3rd edition). USA: Thomson Brooks/Cole.

[38] Sekaran, U., \& Bougie, R. (2013). Research methods for business (6th edition). United Kingdom: John Willey \& Sons Ltd.

[39] Shapiro, S. P. (1987). The social control of impersonal trust. American Journal of Sociology, 93(3), 623-658. doi: https://doi.org/10.1086/228791.

[40] Sindonews.com. (2017, 14 Desember). Korban penipuan belanja online kembali marak di Batam. Diakses pada 3 Oktober 2018. https://daerah.sindonews.com/read/1265705/ 194/korban-penipuan-belanja-online-kembali-marak-di-batam-1513241381.

[41] Srisadono, W. (2018). Strategi perusahaan e-commerce membangun brand community di media sosial dalam meningkatkan omset penjualan. Jurnal Pustaka Komunikasi, 1(1), 167-179. doi: https://doi.org/10.32509/pustakom.v1i1.552.

[42] swa.co.id. (2018, 23 Januari). Prediksi tren e-commerce Indonesia 2018. Di- 
akses pada 5 November 2018. https://swa.co.id/swa/listed-articles/ prediksi-tren-e-commerce-indonesia-2018.

[43] Tiara, K., Sunarya, E., \& Ichsan, M. (2016). Pemanfaatan rekber Blackpanda untuk mengamankan transaksi jual beli online pada situs KASKUS. Seminar Nasional Teknologi Informasi dan Multimedia 2016, 217-222. STMIK AMIKOM Yogyakarta, 6-7 Februari 2016.

[44] Tokopedia. (2018). Mengapa belanja online di Tokopedia aman dan nyaman? Diakses pada 4 Oktober 2018. https:/ /www.tokopedia.com/bebas-penipuan/.

[45] Turban, E., King, D., Lee, J., Liang, T. P., \& Turban, D. 2010. Electronic commerce 2010: A managerial perspective (6th edition). New Jersey: Pearson Education, Inc.

[46] Verhagen, T., Meents, S., \& Tan, Y. H. (2006). Perceived risk and trust associated with purchasing at electronic marketplaces. European Journal of Information Systems, 15(6), 542-555. doi: https://doi.org/10.1057/palgrave.ejis.3000644.

[47] Vos, A., Marinagi, C., Trivellas, P., Eberhagen, N., Skourlas, C., \& Giannakopoulos, G. (2014). Risk reduction strategies in online shopping: Etrust perspective. Procedia-Social and Behavioral Sciences, 147, 418-423. doi: https://doi.org/10.1016/j.sbspro.2014.07.122. 